\title{
SEMIOTIK ROLAND BARTHES PADA CERPEN TUNAS KARYA EKO TUNAS DAN IMPLIKASINYA DALAM PEMBELAJARAN BAHASA INDONESIA
}

\author{
Nurul Panca Putri ${ }^{1}$, Tri Mulyono ${ }^{2}$, Syamsul Anwar ${ }^{3}$ \\ Universitas Pancasakti Tegal \\ Pos-el:nurulpancaputri27@gmail.com ${ }^{1}$, upstrimulyono@gmail.com², \\ syamsulanwar590@gmail.com ${ }^{3}$
}

Diserahkan: 28 Juli 2020, Direvisi: 30 Oktober 2020, Diterima: 11 Februari 2021

\begin{abstract}
The purpose of this paper is to find out the semiotic code sign proposed by Roland Barthes in a collection of short stories by Eko Tunas. Short story by Eko Tunas is full of use of codes in the form of puzzle codes, connotation codes, symbolic codes, action codes and cultural codes. The theory of semiotics can be implicated in the learning of Indonesian class XI in high school in KD 3.8 and 4.8. The short stories studied included 21 titles. Twenty-one short stories were analyzed semiotics to be able to find the code. The method used in this paper is descriptive qualitative describing writing based on the contents of literary works, data collection techniques by reading and recording methods, data analysis techniques using descriptive analysis methods. The results of this study indicate that the short story written by Eko Tunas has a semiotic sign which includes 5 codes. The amount of data reaches 60 data.
\end{abstract}

Keywords: short story, semiotic, Tunas 


\begin{abstract}
Abstrak
Tujuan yang ingin dicapai dari penelitian ini adalah mengetahui tanda kode semiotik yang dikemukakan oleh Roland Barthes pada kumpulan cerpen karya Eko Tunas. Cerpen karya Eko Tunas sarat akan penggunaan kode-kode yang berupa kode teka-teki, kode konotasi, kode simbolik, kode aksian dan kode budaya. Teori mengenai semiotik dapat diimplikkasikan pada pembelajaran bahasa Indonesia kelas XI di SMA pada KD 3.8 dan 4.8. cerpen yang diteliti meliputi 21 judul. Cerpen tersebut dianalisis secara semiotik untuk dapat mengetahui kode. Metode yang digunakan dalam tulisan ini adalah deksriptif kualitatif yang memaparkan tulisan berdasarkan isi karya sastra, teknik pengumpulan data dengan metode membaca dan mencatat, teknik analisis data menggunakan metode deskriptif analisis. Hasil penelitian ini menunjukkan bahwa cerpen yang ditulis Eko Tunas mempunyai tanda semiotik yang meliputi 5 kode. Jumlah data mencapai 60 data.
\end{abstract}

Kata Kunci:cerpen, semiotik, Tunas

\title{
PENDAHULUAN
}

Suatu karya sastra dapat dianalisis dari berbagai sudut pandang yang berbeda-beda, hal tersebut bergantung terhadap jenis pendekatan dan model analisis yang diinginkan.Penikmat sastra banyak yang mengalami kesulitan dalam menafsirkan hal-hal yang diceritakan dalam karya sastra contohnya pada jenis cerpen. Cerpen disajikan dengan struktur yang unik, kompleks kadang tidak dipaparkan maknanya secara langsung menyebabkan pembaca mengalami kesulitan untuk memahami dan memaknai apa yang hendak disampaikan oleh peneliti. Salah satu jenis pendekatan atau model kajian yang biasa digunakan untuk mengkaji cerpen yaitu semiotik.Semiotik merupakan studi yang membahas mengenai tanda.Berarti suatu karya sastra dianalisis sebagai sebuah tandatanda. Seperti diketahui bahwa suatu karya sastra sarat akan tanda, maka tugas dari pembaca yaitu untuk menggali makna-makna yang terdapat dalam karya sastra tersebut. 
Semiotik merupakan ilmu yang di dalamnya mempelajari tentang struktur, dan tanda-tanda dalam penggunaanya di dalam lingkungan masyarakat.Semiotik berasal dari bahasa Yunani, yaitu semion yang berarti tanda, berawal dari kajian tentang bahasa kemudian berkembang menjadi kajian kebudayaan.Semiotik sebagai sebuah bidang kajian sastra sudah banyak dikembangkan oleh para ahli seperti Ferdinan de Sausse, Charles Piere, Umberto Eco, serta Roland Barthes. Ferdinand de Sausse, dikenal sebagai orang pertama yang mengemukakan tentang ilmu semiotik.

Roland Barthes merupakan seorang ahli yang mengemukakan teori semiotik tentang modus transaksi amanat. Ada 5 lima kode untuk memperoleh suatu modus transaksi amanat, yaitu (1) kode teka-teki (the hermeneutic code), (2) kode konotatif (the code of semes or signifiers), (3) kode Simbolik (the symbolic code), (4) kode aksian (the proairetic code), (5) kode budaya (the cultural code or reference code).

Penelitian ini mengangkat masalah bagaimana bentuk kajian semiotik Roland Barthes dalam antologi cerpen Tunas karya Eko Tunas serta implikasinya dalam pembelajaran bahasa Indonesia di SMA. Adapun tujuan dari penelitian ini adalah untuk mengetahui bantuk kajian semiotik Roland Barthes dalam antologi cerpen Tunas karya Eko Tunas dan implikasinya dalam pembelajaran bahasa Indonesia di SMA.

\section{KAJIAN LITERATUR}

Terdapat beberapateori sebagai bahan acuan dalam penelitian ini.Hal ini dilakukan untuk memperkuat temuan-temuan data di lapangan agar memperoleh hasil yang akurat. Teori tersebut meliputi, semiotik, cerpen, dan pembelajaran bahasa Indonesia di SMA.Semiotik merupakan salah satu pendekatan dalam mengkaji sebuah karya sastra yang merupakan lanjutan dari pendekatan strukturalisme.Menurut Junus (dalam Pradopo, 2003:118), semiotik itu merupakan lanjutan atau perkembangan strukturalisme. Pengertian semiotik menurut Pradopo (2003:119) semiotik 
merupakan ilmu tentang tanda-tanda.Ilmu ini menganggap bahwa fenomena sosial/masyarakat dan kebudayaan itu merupakan tandatanda.Adapun menurut Premingger dkk (dalam Pradopo, 2003:119) menyebutkan bahwa studi semiotik sastra adalah usaha untuk menganalisis sistem tanda-tanda.

Sebagai seorang ahli semiotik Roland Barthes dalam tulisannya (Paris: Seuil, 1970) menyebutkan bahwa ada lima kode untuk memperoleh modus transaksi amanat yaitu (1) kode tekateki (the hermeneutic code), (2) kode konotatif (the code of semes or signifiers), (3) kode Simbolik (the symbolic code), (4) kode aksian (the proairetic code), (5) kode budaya (the cultural code or reference code).

\section{Kode Teka-Teki (The Hermeneutic Code)}

Kode teka-teki berkisar pada harapan seorang pembaca untuk mendapatkan suatu "kebenaran" pada pertanyaan yang dimunculkan dalam suatu teks.Kode teka-teki merupakan kode untuk mencari suatu kebenaran yang menampilkan suatu teks dan teka-teki, mencari dan mendapatkan solusi, menunda suatu jawaban. Kode hermeneutik ini dapat mempertajam suatu permasalahan sebuah narasi dan menciptakan pemecahan ataupun suatu jawaban.

\section{Kode Konotatif (The Code of Semes or Signifiers)}

Kata-kata yang digunakan dalam karya sastra merupakan sistem kode ke-2, dan bahasa merupakan sistem kode ke-1. Istilah konotasi dikenal dengan makna sekunder, pada makna konotasi kata-kata biasanya mengalami penyimpangan arti, penggantian arti, dan penyimpangan arti. Penyebab konotatif itu sendiri adalah fakta dalam kehidupan sehari-hari telah mengalami modifikasi, artifisial dan interpretatif yang sesuai dengan konteks action yang diinginkan subjektivitas pengarangnya.Kode konotatif merupakan kode yang memberikan isyarat, menunjukan kiasan suatu makna maupun kemungkinan makna yang ditawarkan oleh sistem penanda. Jika menemukan suatu kumpulan konotasi dengan suatu tema di dalam cerita, sejumlah konotasi biasanya menempel pada suatu nama 
tertentu. Konotasi yang ditampilkan di dalam suatu cerita biasanya berguna untuk memberikan suatu nilai estetika dalam karya sastra tersebut.

\section{Kode Simbolik (The Symbolic Code)}

Kode simbolik merupakan kode yang di dalamnya menawarkan "kontras" pada sebuah teks, seperti feminim-maskulin, terbuka-tertutup dan siang-malam. Istilah simbolik diartikan sebagai dunia perlambangan, dengan kata lain dunia personifikasi manusia dalam menghayati arti kehidupan. Kode simbolik merupakan suatu aspek pengkodean fiksi yang memiliki sifat khas dan struktural.

\section{Kode Aksian}

Kode aksian dikenal juga dengan istilah kode tindakan, kode ini dianggap sebagai pelengkap utama teks yang dibaca oleh orang, artinya suatu karya teks bersifat naratif. Kenyataannya bersifat fiksi, dengan kata lain kode aksi adalah kode tindakan atau narasi yang urutan di dalam tindakan atau cerita.

Kode aksian merupakan prinsip di dalam tuangan bahasa secara tulis perbuatan-perbuatan itu harus disusun secara linier. Sebuah kejadian dalam cerita rekaan tidak mungkin ditampilkan secara serentak, namun ditampilkan secara bertahap sesuai dengan jalan cerita yang diinginkan pengarangnya. Film dan TV menampilkan beberapa peristiwa secara serentak, namun beda halnya dengankarya sastra yang ditulis seperti cerpen dalam tanda tulis tentu akan sulit dan tidak memungkinkan untuk dilakukan secara serentak. Oleh karena itu, suatu perbuatan dan peristiwa harus disusun secara linier. Pada umumnya kronologis peristiwa ditampilkan secara berurutan dari peristiwa A ke B, C, D dan seterusnya. Namun ada juga peristiwa yang ditampilkan secara tidak berurutan.

\section{Kode Budaya (The Cultural Code or Reference Code)}

Kode budaya merupakan peranan metalingual yang terjadi di dalam sastra, dihubungkan dengan realita budaya. Latar belakang sosial budaya yang terdapat di dalam sebuah cerita 
rekaan memungkinkan adanya ikatan dari budaya sebelumnya. Kode budaya yang ditampilkan pada sebuah karya sastra biasanya ditampilkan dengan penggunaan dua bahasa, atau menampilkan ciri khas kebudayaan suatu daerah.

Purba (2010:49) menjelaskan bahwa cerpen adalah salah satu cerita rekaan atau fiksi yang sudah tua usianya. Menurut Sumardjo (dalam Purba, 2010:50) cerpen merupakan fiksi pendek yang selesai dibaca dalam "sekali duduk", cerpen hanya memiliki satu arti krisis dan efek untuk pembacanya. Sejalan dengan Sumardjo, Sudjiman (dalam Purba, 2010:51) bahwa cerpen adalah kisah pendek (kurang dari 10.000 kata) yang dimaksudkan memberikan kesan tunggal dominan.

Materi pembelajaran cerpen terdapat dalam silabus untuk pembelajaran bahasa Indonesia di kelas XI SMA. Pada kompetensi dasar 3.8 dan 4.8 dimana siswa harus mengidentifikasi nilainilai kehidupan yang terkandung dalam kumpulan cerpen, dan mendemostrasikan salah satu nilai kehidupan yang dipelajari dalam cerpen. Kajian semiotik Roland Barthes tentang kode teka-teki, kode konotatif, kode simbolis, kode aksi, dan kode budaya dalam cerpen berguna untuk dapat mengetahui makna yang terkandung dalam sebuah cerpen. Jadi penelitian ini dapat diimplementasikan dalam pembelajaran bahasa Indonesia khususnya di kelas XI.

Sebelum penelitian ini dilakukan, lebih lanjut peneliti dapat membandingkan anatara penelitian yang sedang dilakukan dengan penelitian terdahulu yang memiliki pokok permasalahan dengan teori yang sama. Perbandingan dilakukan agar peneliti tidak dianggap mengutip dari penelitian sebelumnya.

Saptawuryandari pada tahun 2013, dari Badan Bahasa, Kementerian Pendidikan dan Kebudayaan, melakukan penelitian tentang semiotik dengan judul Analisis Semiotik Puisi Chairil Anwar. Adapun hasil penelitian ini adalah tiga puisi milik Chairil Anwar yang memiliki sarana kepuitisan berupa penggunaan gaya bahasa metafora, sinedoks, dan citraan berupa citraan penglihatan, pendengaran, dan rabaan. Persamaan pada penelitian ini terletak 
pada kajian yang digunakan yaitu kajian semiotik.Adapun perbedaannya terletak pada objek penelitian, yaitu pada penelitian sebelumnya mengkaji puisi sedangkan penelitian yang sedang dilakukan yaitu objeknya cerpen. Serta penelitian ini membahas mengenai gaya bahasa, sedangkan penelitian yang sedang dilakukan meneliti tentang makna konotasi dan denotasi.

Astika (2014) dari Universitas Pendidikan Ganesha Bali telah melakukan penelitian skripsi dengan judul Cerpen Kisah Pilot Bejo Karya Budi Dharma (Analisis Semiotika Roland Barthes). Menelaah tentang kode aksi, kode hermeneutika, kode kebudayaan, kode konotatif dan kode simbolik yang terdapat di dalam cerpen Kisah Pilot Bejo.Persamaan pada penelitian ini terletak pada kajian yang digunakan yaitu kajian semiotik Roland Barthes. Adapun perbedaannya objek yang diteliti, pada penelitian ini mengkaji tentang satu cerpen, sedangkan penelitian yang akan dilakukan objek yang diteliti antologi cerpen Tunas.

Sudarto (2015) melakukan sebuah penelitian dengan judul Analisis Semiotika Film Alangkah Lucunya Negeri Ini.dalam penelitian ini ditemukan hasil makna konotasi, makna denotasi, dan makna mitos. Makna yang ditemukan dalam penelitian ini terdapat di dalam 6 scene. Adapun scene 1 pada durasi (00:01:19-00:02:09), scene 2 pada durasi (00:02:56-00:03:52), scene 3 (00:03:54-00:04:52), scene 4 (00:06:40-00:08:00), scene 5 (00:43:00-00:46:29), dan scene 6 pada durasi (01:38:14-01:40:06). Persamaan pada penelitian ini terletak pada kajian yang digunakan yaitu kajian semiotik Roland Barthes. Adapun perbedaannya yaitu pada jenis kajiannya, pada penelitian ini membahas konotasi, denotasi, dan mitos. Sedangkan penelitian yang akan dilakukan akan mengkaji 5 kode Roland Barthes.

Agustina (2016) dari Universitas Muhammadiyah Purwokerto, melakukan penelitian dengan judul Analisis Semiotik Roland Barthes Novel Hujan Karya Tere Liye dan Rencana Pelaksanaan Pembelajarannya di Kelas XI SMA.Hasil penelitiannya adalah penjelasan tentang unsur pembangun novel seperti tema, tokoh dan penokohan, alur, latar, dan sudut pandang.Selain itu, 
juga menjelaskan tentang telaah kode hermeneutika, kode semik (kode konotatif), kode simbolik, kode preoretik (kode tindakan) dan kode gnomik (kultural).Persamaan pada penelitian ini terletak pada kajian yang digunakan yaitu kajian semiotik Roland Barthes. Adapun perbedaannya yaitu pada penelitian sebelumnya mengkaji novel, sedangkan penelitian yang dilakukan objeknya berupa cerpen. Dalam penelitian ini membahas mengenai kode hermeneutika, kode semik (kode konotatif), kode simbolik, kode preoretik (kode tindakan) dan kode gnomik (kultural) yang menunjukan sama-sama akan membahas mengenai 5 kode.

Syakur dkk (2018) pada jurnal International Journal of Linguistics, Literature And Culture yang berjudul Text of Cigarette Advertisement: A Semiology Study of Roland Barthes. Objek yang diteliti yaitu iklan produk rokok A-Mild yang ditampilkan di kota Mataram dan dianalisis menggunakan pendekatan semiotik Roland Barthes. Penelitian ini berfokus pada mitos yang dibangun melalui penanda serta bagaimana pengaruh simbol iklan rokok A-Mild terhadap pembaca, terutama kaum muda. Perbedaan penelitian jelas pada objek penelitian yaitu iklan produk rokok A-Mild sedangkan penelian yang sedang dilakukan yaitu berobjek kumpulan puisi. Selain itu, pendekatan semiotiknya juga berbeda penelitian ini menggunakan teori mitos yang dikemukakan oleh Roland Barthes, sedangkan penelitian yang akan dilakukan menggunakan teori Roland Barthes 5 kode, kode hermeneutik, kode semik, kode simbolis, kode proairetik, dan kode budaya. Persamaan terletak pada teori yang bersumber pada ahli semiotik Roland Barthes.

\section{METODE PENELITIAN}

Penelitian ini menggunakan jenis penelitian deskriptif kualitatif, menurut Sugiyono (2015:14) penelitian kualitatif merupakan metode penelitian naturalistik karena penelitiannya dilakukan pada kondisi alamiah, data yang terkumpul dan analisisnya lebih bersifat kualitatif.Data yang dihasilkan dalam penelitian ini berupa data verbal yang tidak dikuantitatifkan berupa 
angka. Data yang telah dikumpulkan nantinya akan dianalisis menggunakan metode deskriptif. Pendekatan yang digunakan dalam penelitian ini adalah pendekatan objektif dimana objek yang diteliti berupa karya sastra itu sendiri.Menurut Arikunto (2013: 61) prosedur penelitian dijelaskan dengan langkah-langkah penelitian yang lebih menitikberatkan pada kegiatan administratif, yaitu, pembuatan rancangan penelitian (prapenelitian), pelaksanaan penelitian, dan pembuatan laporan penelitian (pascapenelitian). Sumber data dalam penelitian ini adalah antologi cerpen Tunas karya Eko Tunas yang diterbitkan oleh Cipta Kreasi Anak Indonesia (CRESINDO), pada bulan Maret 2013. Data-data tersebut berupa kata-kata yang mengandung kode teka-teki, kode konotatif, kode simbolik, kode aksian, dan kode budaya.Sumber data penelitian ini berupa kumpulan cerpenTunas karya Eko Tunas yang terdiri dari 21 judul cerpen.Penelitian ini dalam pengumpulan data menggunakan teknik baca dan catat secara runtut.Setelah data yang diperlukan telah terkumpul, selanjutnya peneliti melakukan analisis data.Dapat dijelaskan bahwa penelitian ini menggunakan metode deskriptif analisis, jadi deskripsi analisis berarti menguraikan.Bukan hanya menganalisis tetapi menjelaskan serta memberikan pemahaman.

\section{HASIL PENELITIAN DAN PEMBAHASAN}

Penelitian ini membahas semiotik Roland Barthes pada kumpulan cerpen Tunas karya Eko Tunas dan implikasinya pada pembelajaran bahasa Indonesia di SMA. Kumpulan cerpen Eko Tunas di dalamnya terdapat 21 judul cerpen, yaitu "Ia Menangisi Dirinya”, "Dremayon”, “Banjir Kanal”, Boarding Pakeliran”, "Lubang Air", "Biduan Goyang", "Kamar Kecil dan Seorang Wanita”, "Panggung Perempuan", "Bidadari dalam Cahaya Putih", "Peluru untuk Ayah", “Taman Air Mata”, "Air Mata Daun”, “Tikus Cantik”, “Anjing Sedap Malam", "Sebuah Pertanyaan untuk Peluru”, "Pesta Sampah", "Cinta Angin Gurun”, "Babi Kemnang Plastik", "Lelawa Peri Parabola”, "Sapi Tersalib Pedati”, dan "Apel Bersayap Sembilu”. Kedua puluh satu cerpen tersebut dianalisis unsur semiotiknya, yaitu dengan semiotik aliran Roland Barthes yang terdiri atas lima kode, yaitu(1) 
kode teka-teki (the hermeneutic code), (2) kode konotatif (the code of semes or signifiers), (3) kode simbolik (the symbolic code),(4) kode aksianan (the proairetic code), (5) kode budaya (the cultural code or reference code).

\section{Kode Teka-Teki (Hermeneutic Code) \\ Data 1}

“O, betapapun kami manusia lemah di hadapan-Mu, Tuhan. Ya, benarkah ini campur tangan-Mu, jika hulu digundulkan dan perbukitan dan area perkebunan dipapraskan: di sana bahkan akan berdiri kota satelit, setelah perumnas, real estate, vila-vilahotel, tempat hiburandan wisata hutan. Petani, pemilik perkebunan buah, kaum boro, dengan terpaksa mengikhlaskan pembelian murah atas area tanah lading produktif mereka...." (Banjir Kanal, 1990:26)

Berdasarkan kutipan di atas menunjukkan adanya kode teka-teki,kode tersebut disusun pengarang menggunakan paragraf. Adapun kode teka-teki yang ditampilkan mengenai ucapan seorang tokoh Insani yang menanyakan apakah karena adanya capur tangan kekuasaan Tuhan, sehingga menyebabkan banyaknya pembangunan, yaitu hulu yang telah digundulkan dan sekarang dibangun sebuah perumahan, hotel dan lain-lain.

\section{Data 2}

"Sakit hati macam apa ini ...? " O, Tuhan, desah Insani, betapaku baru memahami kakekku di Kedungombo yang sedumuk bathuk sanyari bumi bertahan diantara genangan air waduk yang perlahan tapi pasti akan melahap tanah dan rumah miliknya...."(Banjir Kanal, 1990 : 27)

Berdasarkan kutipan di atas menunjukanadanya kode tekateki, saat tokoh Insani yang sudah pasrah kepada sang pencipta atas apa yang akan terjadi pada kehidupannya, salah satunya yaitu adanya bencana banjir karena banyaknya pembangunan. Teka-teki yang ditampilkan tokoh Insani yang tidak mengetahui kehidupan kedepannya akan seperti apa. 


\section{Data 3}

"Di bawah langit kelam menghitam, hujan mengguyur, dan air yang mengamuk tubuhku tertahan di satu pohon.Dalam giris, dalam tangis batin mengiris, aku saksikan tubuh-tubuh terseret tenggelam. Tangan-tangan menggapai, oh sudah tibakah hari kiamat, setelah aku baca tanda-tanda zaman atas kiamat struktural...."(Banjir Kanal, 1990 : 29-30)

Berdasarkan kutipan di atas memperlihatkan kode hermeneutik. Teka-teki saat terjadinya bencana banjir yang dialami oleh Insani, saat banjir iatertahan pada pohon, dan menyaksikan orang-orang terseret air dan mulai tenggelam. Teka-teki juga diperlihatkan saat tokoh Insani yang penasaran dan mengira apakah ini merupakan suatu kiamat karena dahsyatnya bencana yang terjadi.

\section{Data 4}

"Tiba-tiba suara wanita memanggilnya dari arah belakang.Ia menoleh, ternyata ibunya yang berdiri menggapaikan tangan. Dalam keterpanaan ia menggigit bibir. Benarkah itu sosok ibunya, apakah ia tidak sedang bermimpi. Bukankah ibunya tewas setahun lalu dalam pesawat yang gagal melakukan pendaratan." (Boarding Pakeliran, 2007:33)

Berdasarkan kutipan di atas, memperlihatkan kode teka-teki, saat munculnya sosok wanita yang memanggil dari arah belakang dan diceritakan sebagai ibunya, namun pada kenyataannya bahwa ibunya telah tewas dalam kecelakaan pesawat satu tahun yang lalu. Pembaca dibuat penasaran dengan teka-teki mengenai sosok wanita tersebut.

\section{Data 5}

"Tidak pernah kau bayangkan, bagaimana perasaan anakanak dan istrimu?Apalagi mereka biasa hidup tata tentrem karta raharja.Semuanya seperti berjalan begitu saja, tanpa aku bisa mengelakkan...." (Boarding Pakeliran, 2007: 36-37) 
Berdasarkan kutipan di atas terlihat adanya kode teka-teki. Teka-teki tentang penggambaran perasaan anak-anak dan istri tokoh Rahwan saat mengetahui bahwa Rahwan selingkuh dengan tokoh Sita yang diceritakan sebagai seorang artis.

\section{Kode Konotasi}

\section{Data 6}

"Terutama isteri Burna dan anak-anak mereka sudah pasrah bongkokan kepadanya dan Monica. Dan Sanu cukup senang karena keluarga kakaknya sudah tampak kembali menampakkan sayap-sayap kebahagiaan." (Bidadari dalam Cahaya Putih, 2009:93).

Berdasarkan kutipan di atas, menampilkan adanya kode semantik atau konotatif, yaitu pada penafsiran tokoh Burna sebagai orang yang telah lama hidup terpuruk dan terbelenggu oleh masa lalu. Permasalahan masa lalu membuat dirinya seperti orang gila karena kekalahan pilkada dan kasus illegal loging yang sedang diselidiki oleh Komisi Pemberantasan Korupsi.Namun setelah Burna mendapat terapi kejiwaan dari Monica, kini telah menunjukan tanda-tanda kesembuhan dan kembali bangkit.Burna memulai kehidupan yang lebih baik dengan penuh kebahagiaan.Namun pada cerita ditampilkan dengan ungkapan menampakkan sayap-sayap kebahagiaan.

\section{Data 7}

"Kenapa kamu?"

"Karena aku orang besar, yang tidak tahu ada anjing tidur di bawah kakiku...."

Saat itu aku tertawa,

"Orang besar...?"

"Kau lupa, aku pernah berkunjung ke kota-kota dunia...!?”

Dan kau menyanyi sambil bergitar,

“New York... New York...”(Taman Air Mata, 2008:109) 
Berdasarkan kutipan di atas, menampilkan penggunaankode konotatif, yakni ungkapan orang besar. Ungkapan tersebut memiliki makna bahwa orang yang memiliki kedudukan, kekuasaan, jabatan. Dalam istilah denotasi orang besar diartikan sebagai orang yang memiliki tubuh besar, besar memiliki arti tinggi dan berat badan yang lebih.

\section{Data 8}

"Agar tidak ketinggalan zaman, agar tidak ketinggalan kereta dunia, agar tidak tetap dikenal sebagai bangsa tempe.Bangsa kita harus menguasai teknologi, mau tidak mau, dan itu memang butuh pengorbanan." (Banjir Kanal, 1990:25)

Kutipan di atas menampilkan bacaan yang mengandung makna konotatif yaitu pada ungkapan bangsa tempe.Ungkapan ini mengandung penafsiran bahwa bangsa yang masih tradisional, ketinggalan zaman dalam hal penggunaan teknologi. Bangsa tempe yang dalam melakukan kegiatan masih bersifat manual, mengandalkan tenaga manusia, tidak ada bantuan mesin sebagai bentuk kemajuan ilmu pengetahuan dan teknologi.

\section{Data 9}

"Milikmukah semua itu?Bukankah kau sawo matang dan tak bermata sipit?Meski nama-nama yang menceloteh di antara grafiti itu sebagaimana nama-namamu. Nama-nama yang juga tertulis di dinding kamarku...." (Taman Air Mata, 2008:110)

Berdasarkan kutipan di atas, terdapat ungkapan yang memiliki maknakode konotatif, yaitu pada ungkapansawo matang, ungkapan ini memiliki arti penggambarkan seseorang yang memiliki warna kulit coklat gelap seperti buah sawo yang telah matang.

\section{Kode Simbolik}

\section{Data 10}

"Aku sendiri merasa heran mengingat energi mereka, terutama Rae yang sudah berusia tetapi bertenaga dinamit. Setelah aksi demo seharian yang melelahkan, semangat 
mereka masih tetap menyala-nyala untuk membicarakan sang despot yang mesti berhasil mereka gulingkan...." (Ia Menangisi Dirinya, 2008:6)

Berdasarkan kutipan di atas, menunjukan adanya penggunaan kode simbolik saat Rae yang digambarkan sudah berusia. Berusia disini diartikan memiliki umur 50 tahun atau 60 tahun lebih tetapi masih memiliki tenaga yang dinamit yaitu masih sangat kuat diusia lanjut, tidak seperti kebanyakan orang saat berusia lanjut. Orang usia lanjut identik dengan kondisi yang sudah lemah, inilah yang menunjukkan simbolik.

\section{Data 11}

"Gedung-gedung berasitektur modern tanpa meninggalkan nilai-nilai lama. Bagai permata kristal keemasan dalam cahaya lampu kemilau dan taman gemerlap.Ia berjalan kaki diantara lalu lintas yang teratur, dan orang-orang dari berbagai bangsa." (Cinta Angin Gurun, 2010:167)

Berdasarkan kutipan di atas, menampilkan adanya kode simbolik karena memperlihatkan sesuatu yang berkebalikan, yaitugedung yang berasitektur modern mengikuti kemegahan zaman dan keberagaman model tetapi masih mempertahankan dan menyimpan nilai-nilai lama yang bersifat tradisional.Tradisional ini ditampilkan dengan bangunan gedung yang memiliki sentuhan tradisional yang sederhana dan sarat makna.

\section{Data 12}

"Bibir Sadijah tetap menyenyum. Meski galau pikirannya diam-diam mempertanyakan. Bukankah Andit adalah salah satu putra bangsa yang dibanggakan Bung Karno. Kenapa nasibnya tak seperti yang diharapkan akan bayangan seorang insinyur Amerika. Andit memang tampak sulit mau menjelaskan keberadaanya. Tapi satu lintasan pikiran cukup mengarahkan kegalauannya, pada pertanyaan: apakah ini karena sekarang zamannya presiden baru yang menggantikan presiden Soekarno?” (Apel Bersayap Sembilu, 2006:217) 
Berdasarkan kutipan di atas menampilkan adanya kode simbolik, tokohAndit yang digambarkan sebagai salah satu putra bangsa yang memiliki prestasi dan dibanggakan oleh bung Karno tetapi nasibnya tidak seperti layaknya insinyur Amerika.Hal ini menunjukkan sesuatu yang berkebalikan, yakni tokoh Andit yang seharusnya memiliki kehidupan yang baik, namun nyatanya tidak.

\section{Kode Aksian}

\section{Data 13}

"Dia cocok menjadi pemimpin masa depan," desak Rae tempo hari, begitu situasi politik mulai memanas.

“Memimpin siapa?" tohokku.

"Memimpin dan mengubah bangsa ini demi hari depan yang lebih baik" tak sadar aku ngakak.

“Kenapa?"protes Rae.

"Selama ini kita salah pilih kan?"

Rae menghela serangkum napas.

"Yah..." desahnya,

"Banyak sebenarnya orang-orang terpercaya. Terutama mereka yang datang dari kalangan muda.... (Ia Menangisi Dirinya, 2008:9)

Berdasarkan kutipan di atas terlihat adanya kode yang menunjukan aksian atau tindakan suatu tokoh. Saat tokoh aku dan Rae sedang membicarakan tentang pemimpin, disela-sela pembicaraan tokoh aku ngakak (tertawa terbahak-bahak), serta tokoh Rae yang menghela napas, menunjukkan adanya tindakan setelah terjadinya percakapan.Aksi dipicu oleh pembicaraan mengenai politik dan pemimpin.

\section{Data 14}

Selesai membaca sambil ketawa tergelak-gelak suaminya pun berkata "Jelas, orang Amerika itu malu ketemu Andit. Dia dianggap ahli padahal Andit tentu jauh lebih ahli. Andit lulus cumlaude, dan dia mahasiswa paling bodoh!" 
kemudian decaknya. "Begitulah macamnya orang-orang kita sekarang, semua yang dari luar negeri, apalagi dari Amerika selalu dianggap lebih unggul. Padahal kenyataannya nol besar!”(Apel Bersayap Sembilu, 2006:218-219)

Berdasarkan kutipan di atas menunjukan adanya kode aksian dari tokoh suami yang tertawa lepas setelah membaca surat. Pada cerita dijelaskan bahwa Andit seorang insinyur lulusan Amerika yang lulus dengan predikat cumlaude, dan temannya yang merupakan mahasiswa paling bodoh. Namun di Indonesia dianggap unggul dan berprestasi, itulah yang membuat tokoh ayah beraksi tertawa lepas, karena tidak semua lulusan luar negeri unggul, nyatanya teman Andit nol besar.

\section{Kode Budaya}

\section{Data 15}

"Alasannya selalu itu-itu juga, di tengah kami bicara ngalorngidul: hanya aku yang bisa diajak bicara. Terutama soalsoal, yang menurut istilahnya, sosio-politiko-historis. Satu hal yang sebenarnya tidak aku suka, tapi sekadar menyenangkan teman aku selalu berusaha meladeni. Aku sebenarnya lebih suka berbicara tentang rumahnya, yang menurutku cocok untuk dijadikan ruang pameran, diskusi seni, atau baca puisi." (Ia Menangisi Dirinya, 2008:4)

Berdasarkan kutipan di atas, menunjukan kata-kata yangmemperlihatkan adanya kode budaya, yaitu adanya penggunaan bahasa jawa ngalor-ngidulserta bahasa asing yaitu "sosio-politikohistoris". Hal ini menunjukkan adanya pengaruh budaya asing serta penggunaan bahasa jawa, yakni bercampurnya bahasa yang digunakan menunjukan kode budaya menurut teori semiotik Roland Barthes.Kata ngalor-ngidulmemiliki arti utara-selatan.

\section{Data 16}

"Tapi manusia mesti bercinta, " tukasnya sigap,

"itulah kenapa manusia hidup. Kalau mati kan, selesai, tamat, the end!". 
"Apakah kau sungguh mencintaiku?"

"Mungkin aku salah mengurus diriku, tapi aku tak mau ditinggalkan."

"Apakah ada manusia yang bisa mengurus hidupnya lebih pintar dari....(Boarding Pakeliran, 2007:35)

Berdasarkan kutipan di atas, terlihat adanya kode budaya yang ada di dalam cerita penggunaan bahasa asing dalam ucapannya yaitu kata the end yang memiliki arti tamat atau selesai.Percampuran bahasa merupakan salah satu kategori kode budaya, yaitu bahasa Inggris, percampuran bahasa dikenal dengan istilah campur kode, atau alih kode.

\section{Data 13}

"Ingatannya melayang ke beberapa tahun lalu.Saat dirinya menunggu $d u l$ bersama Andit.Anak kesayangannya yang pintar dan serba ingin tahu.Ingin melihat petasan besar itu dibunyikan di tengah lapangan Alun-alun. Dan ia selalu khawatir kalau Andit melihatnya dari jarak yang pada pikirannya begitu dekat. Ah, Andit yang tidak sukamakanan rakyat, tapi lebih menyukai ice cream dan pizza yang mesti beli di Toko Liem. Toko yang di masa pendudukan Belanda sebagai tempat makan-minum tuan-tuan dan nyonya-nyonya bule."(Apel Bersayap Sembilu, 2006:214)

Berdasarkan pada kutipan di atas, menunjukkan adanya penggunaan kode budaya, yaitu penggunaan bahasa asing untuk bebrapa kata.Hal ini menunjukkan masuknya budaya barat dengan adanya percampuran bahasa yang digunakan yaitu penggunaan bahasa Inggris.Kata-kata yang menunjukan bahasa asing ditulis dengan cetak miring seperti ice crem, pizza, ice crem, pizza merupakan makanan khas dari negara Italia, selain penggunaan bahasa asing yaitu makanan yang dikonsumsi dari luar Indonesia.

Semiotik yang terdapat di dalam cerpen Tunas terdapat 5 jenis tanda, yaitu kode teka-teki, kode, konotasi, kode simbolik, kode aksi dan kode budaya. Hasil penelitian menujukkan terdapat 60 data yang terdiri atas, 18 data kode teka-teki, 18 data kode konotasi, 
9 data kode simbolik, 6 data kode aksi dan 9 data kode budaya. Penelitian ini dapat diimplementasikan dalam pembelajaran bahasa Indonesia pada materi cerpen kelas XI SMA. Hal ini mengacu pada silabus tepatnya pada kompetensi dasar 3.8 dan 4.8.Pada KDtersebut menyebutkan bahwa 3.8 mengidentifikasi nilai-nilai kehidupan yang terkandung dalam kumpulan cerpen yang dibaca.Adapun 4.8 mendemonstrasikan salah satu nilai kehidupan yang dipelajari dalam cerpen.

\section{PENUTUP}

Bentuk semiotik Roland Barthes yang terdapat dalam kumpulan cerpenTunas karya Eko Tunas meliputi 5 kode yaitu, (1) kode teka-teki (the hermeneutic code), (2) kode konotatif (the code of semes or signifiers), (3) kode simbolik (the symbolic code), (4) kode aksian (the proairetic code), (5) kode budaya (the cultural code or reference code). Jumlah data mencapai 60 yang terdiri atas 18 data untuk kode teka-teki dengan persentase 30\%, 18 data untuk kode konotatif dengan persentase 30\%, 9 data untuk kode simbolis dengan persentase 15\%, 6 data untuk aksi dengan persentase $10 \%$, dan 9 data untuk kode teka-teki dengan persentase $15 \%$. Penelitian ini dapat diimplementasikan pada pembelajaran bahasa Indonesia kelas XI kompetensi dasar 3.8 mengidentifikasi nilai-nilai kehidupan yang terkandung dalam kumpulan cerpen yang dibaca. 4.8 mendemonstrasikan salah satu nilai kehidupan yang dipelajari dalam cerpen.Berdasarkan hasil penelitian dan simpulan yang telah dipaparkan, maka peneliti dapat memberikan saran sebagai berikut. Siswa diharapkan dapat meningkatkan kebiasaan membaca cerpen, menganalisiscerpen agar dapat mengidentifikasi nilai-nilai yang terdapat di dalamnya, sehingga mampu menerapkan dalam kehidupan sehari-hari. Siswa diharapkan mampu mengetahui tentang pengertian, penggunaan tanda atau kode dalam cerpen khususnya teori tanda yang dikemukakan oleh Roland Barthes. Guru bahasa Indonesia dapat menggunakan kumpulan cerpen Tunas karya Eko Tunas sebagai bahan materi dalam mengajar di kelas. 


\section{DAFTAR PUSTAKA}

Ahmad Abdun Syakur, R. M. (2018). Text of Cigarette Advertisement: A Semiology Study of Roland Barthes.International Journal of Linguistics, Literature and Culture, IV(3), 72-79.

Anri Barkah, A. K. (2016). Analisis Struktural Semiotik pada Makna Puisi Karya Siswa SD Negeri 1 Mekarharia Banjar.

Arikunto, S. (2013).Prosedur Penelitian Suatu Pendekatan Praktik. Jakarta: Rineka Cipta.

Astika, I. M. (2014).Cerpen "Kisah Pilot Bejo" Karya Budi Darma (Analisis Semiotika Roland Barthes).PRASI, 9(18), 15-28.

Friska Dewi Yuliyanti, A. B. (2017). Representasi Maskulinitas Dalam Iklan Televisi Pond's Men \#Lelakimasakini(Analisis Semiotika Roland Barthes Terhadap Representasi Maskulinitas).Jurnal Komunikasi, 9(1), 16-30.

Lina Meriaty Simbolon, B. A. (2019). The Study of Semiotics In Cinta Di Dalam Gelas Novel By Andrea Hirata As Literature Reading Material In Senior High Schools.Internasional Journal of Education, Learning and Development, 7(5), 21-34.

Pradopo, R. D. (1995). Beberapa Teori Sastra, Metode Kritik, dan Penerapannya. Yogyakarta: Pustakapelajar.

Purba, A. (2010). Sastra Indonesia Kontemporer. Yogyakarta: Graha Ilmu.

Putu Krisdiana Nara Kusuma, I. K. (2017).Analisis Semiotika Roland Barthes pada Ritual Otonan di Bali.Jurnal Manajemen Komunikasi, 1(2), 195-2017.

Saptawuryandari, N. (2013). Analisis Semiotik Puisi Chairil Anwar. Kandai, 9(1), 95-104.

Sinta Rizki Haryono, D. K. (2017). Identitas Budaya Indonesia: Analisis Semiotika Roland Barthes. Acta diurna, 13(2), 67- 88.

Sobur, A. (2006). Semiotika Komunikasi. Bandung: Rosdakarya. 
Sugiyono. (2015). Metode Penelitian Pendidikan Pendekatan Kuantitatif, Kualitatif, dan R\&D.Bandung : Alfabeta.

Sugiyono.(2017). Metode Penelitian Kombinasi (Mixed Methods). Bandung: Alfabeta.

Tunas, Eko.(2013). TUNAS. Tegal: Cresindo.

Vered Tohar, M. A. (2007). An Alternative Approach For Personal Narrative Interpretation: The Semiotics of Roland Barthes. International Journal of Qualitative Methods, IV(3), 57-70. 